\title{
In Search of an Effective Teacher: Ghana's Move towards Achieving Sustainable Education through Teacher Education Reforms
}

\author{
Kenneth Adu-Gyamfi ${ }^{1}$ \& Deodat Charles Otami ${ }^{1}$ \\ ${ }^{1}$ Department of Science Education, Faculty of Science and Technology Education, College of Education Studies, \\ University of Cape Coast, Ghana \\ Correspondence: Kenneth Adu-Gyamfi, Department of Science Education, Faculty of Science and Technology \\ Education, College of Education Studies, University of Cape Coast, P. O. Box PBM, Cape Coast, Ghana.
}

Received: May 16, 2020

Accepted: June 18, 2020

Online Published: June 19, 2020

doi:10.5430/ijhe.v9n4p216

URL: https://doi.org/10.5430/ijhe.v9n4p216

\begin{abstract}
Ghana has experienced a number of education reforms in the post-independence era and the study examined Ghana's attempt at understanding what constitutes an effective teacher, in relation to sustainable education, through teacher education reforms. Qualitative approaches, such as documents analysis and interviews with 10 experienced college educators, were the methodology for the research. After constant comparison, students' quality and entry requirements, changes in curriculum, and role of development partners in education reforms affected the quality of teacher education. However, cultural context, support systems, and educator professional development are means of achieving sustainable basic education. Ghana should, therefore, have teacher education policies, uninfluenced by changes in political power and ideologies, but tailored to socio-cultural and economic needs of the people; preparing motivated-teachers to accept the profession as a chosen-career.
\end{abstract}

Keywords: curriculum, effective, reforms, review, sustainable, teacher education

\section{Introduction}

Historically, the education sector in every country experienced reforms and Adu-Gyamfi, Donkoh, and Adinkrah (2016) noted that reforms in education are attempts to make changes in policy, practices, or organization, or to address an identified issue. Educational reforms help to better the education system and in Ghana, almost every change in political power brings a change to the country's educational system (Adu-Gyamfi et al., 2016; ICET, 2012). According to Akyeampong (2010), every 5 years Ghana introduces another form of reform. For instance, the government of New Patriotic Party (NPP) between 2001-2008 saw that the 1987 education reforms of the then Provisional National Defence Council (PNDC) government was bedeviled with problems in objectives, content, administration, and management (Ministry of Education, Youth and Sports [MEYS], 2004). The 2004 education reform was initiated on the premise that many policies failed to meet the expectations of Ghanaians in relation to public education system, specifically to make education more relevant to the workplace, something that has not been met by previous reforms (MEYS, 2004). The Accelerated Development Plan of Education of 1951 under the government of the Convention People's Party (CPP) failed in the standard of education at elementary and secondary education, and created a massive unemployment situation in Ghana (MEYS, 2004).

The Kwapong Review Committee of 1966 under the government of National Liberation Council (NLC) effectively managed the number of students transiting from elementary school into secondary 'grammar' school, with the introduction of continuation schools (Akyeampong, 2010; MEYS, 2004). However, the 1966 education review failed in nurturing the teenage population through the process of post-primary training (MEYS, 2004). The Dzobo Review Committee of 1974 under the government of National Redemption Council (NRC) brought about the concept of comprehensive junior secondary school (JSS) (Akyeampong, 2010; MEYS, 2004), that intended to teach all pupils academic and practical skills. The concept became effective in the 1987 primary and junior secondary schools combining to form basic education (Akyeampong, 2010), but still failed to address the large number of teenagers leaving JSS that were ill-prepared in basic numeracy and literacy skills needed for second cycle institutions (MEYS, 2004). The 2002 Committee on Review of Education Reforms under the government of the then NPP, made unique recommendations for changing the 3-year senior secondary school to 4-year senior high school (MEYS, 2004). In all these reforms, teacher education in Ghana started receiving the needed attention at the implementation of the 1987 pre-tertiary education reforms (Akyeampong, 2003). 
Globally, most countries have made several attempts to prepare a teaching work-force for the quality of school education, and Ghana is no exception of (Asare \& Nti, 2014). Ghana has institutions outside the traditional universities that prepare pre-service teachers for basic schools. Teacher education in these institutions was termed as Initial Teacher Training (Ministry of Education [MOE), 1993). The 2002 Committee to review the Education Reforms identified that there were problems with Teacher Education in Ghana, specifically, that there was insufficient training of teachers from the initial teacher training colleges (MEYS, 2004). The following recommendations were made by the 2002 committee in relation to teacher education:

1. A teaching and licensing coordinating body, the National Teaching Council, will be established.

2. All Teacher Training Colleges will be upgraded into diploma-awarding institutions, which will be affiliated to the education-oriented universities.

3. Remedial programmes will be provided for teachers without the minimum requirements to enter teacher-training colleges.

4. Special attention will be given to the training of teachers for technical, agricultural, vocational, and special education, and in French.

5. Conditions of service will be improved to make the teaching profession attractive and to inspire confidence and efficiency.

6. Special training will be given to teachers who opt for Guidance and Counselling programmes.

7. Incentives will be offered to encourage teachers to transfer from the urban centers to rural areas (MEYS, 2004, pp. 30-32).

In an attempt to improve the quality of initial teacher education, the then teacher training colleges, were upgraded to colleges of education of similar status to that of traditional universities or polytechnics. This affiliated colleges to traditional universities instead of the Ministry of Education and accredited by the National Accreditation Board (MEYS, 2004). This move affected teacher education and anything that affects teachers affects teaching with rippling effects on education (International Council on Education for Teaching [ICET], 2012). Anamuah-Mensah noted that "in order to prepare students for the future and not the past, educational systems must be re-designed to embrace change. To do this, teacher education must be transformed to prepare teachers to handle change and be change agents themselves" (ICET, 2012, p. 7). This is because "teacher education is the medium for transmitting skills, behaviours, values, and knowledge which are considered necessary to live a happy and successful life" (Matunhu, 2012, p. 298).

According to Matunhu (2012), teacher education is the formal education that involves teachers undergoing learning experiences in the preparation of professional agents; transmitting knowledge, skills, and attitudes to society. However, education in Africa is short of producing a 'perfect' teacher for the African citizens. Teacher education goes through changes as every education reforms requires efficient teachers to implement these reforms. Hence, there cannot be education reforms without examining the country's teacher education system (Asare \& Nti, 2014). Anamuah-Mensah and Benneh outlined various forms of teacher education programmes in Ghana. Those in the colleges of education included:

1. Three-year Diploma in Basic Education - regular mode.

2. Four-year Diploma in Basic Education - distance mode for the non-professional teachers.

3. Two-year Diploma in Basic Education - sandwich mode for professional Certificate 'A' teachers.

4. Three-year Bachelor of Education - sandwich mode for professional diploma in basic education teachers to upgrade to secondary teacher education.

5. Two-year Post-Diploma in Basic Education - sandwich mode.

6. Three-year Post-Diploma in Basic Education -distance mode (Asare \& Nti, 2014).

The 1987 education reform programme targeted to increase access to teacher education, improve education input, and restructure the education system. It must be noted that prior to the implementation of the 1987 education reform programme, education in Ghana was structure as 6 years primary education, 4 years middle school education, 7 years secondary school education, and 3-4 years tertiary education. For this and other reasons, Ghana's education was considered as one of the best in Sub-Saharan Africa in the 1960 (Akyeampong, 2010). According to MOE (n.d.), this has declined and has resulted in a number of reforms in teacher education with the intent of supplying basic schools with effective teachers. MOE believed that effective teachers can help Ghana achieve the goal of Free Compulsory Universal Basic Education (FCUBE) and SDG4, quality (inclusive and equitable) basic education for all persons 
(United Nations, 2017; 2019).

The evaluation conducted by the 1994 Education Reform Review Committee resulted in the implementation of the FCUBE in 1996 (Akyeampong, 2004; 2010), and the policy aimed at addressing the weaknesses of the 1987 education reform programme. After 5 years of the 1987 education reform programme, it became evident that much was needed to influence student learning outcomes, and providing effective teacher education programmes resulting in quality trained teachers was suggested (Akyeampong, 2003). Effective teacher education came into the question, as the 1992 criterion-referenced test report revealed that although the student learning outcome in basic education was weak, students from private schools manned by unprofessional teachers out-performed students from public schools with professional teachers (Akyeampong, 2003).

Teacher education curriculum is often ad hoc, as any reform at this level is governed by statutory bodies (Akyeampong, 2003; Forlin, 2010). Ghana, like other countries, has teacher education that may not be effective as the system lacks structure meeting the demands of time (Akyeampong, 2003). For instance, from the 1993 to-date, the entry requirement for candidates into colleges of education were ' $\mathrm{O}$ ' level certificate and senior secondary certificate examination holders. The Teacher Education Division under the Ghana Education Service screened the applicants to ensure quality. The screened applicants were interviewed by the respective college of education for the final selection (Akyeampong, 2003). After 2010, the interview-mode of selection of applicants was abolished and were selected based only on the ' $\mathrm{O}$ ' level and senior secondary certificate examination passes (Institute of Education [IOE], 2014). In all these changes, the views of teacher educators were overlooked by policymakers (Akyeampong, 2017).

IOE (2014) introduced a new curriculum to give a new direction to the preparation of teachers, ensuring quality education for students in basic schools. The content of the curriculum offered pre-service teachers an opportunity to pursue 4-year bachelor in education from accredited teacher education universities upon completion. The curriculum will offer pre-service teachers the opportunity to become generalist teacher capable of teaching all subjects in both primary and junior high schools, and specialist teachers capable of teaching either science, mathematics, technical skills, or French in junior high school, or early childhood education.

According to United Nations (2017), a threat to achieving the sustainable development goal (SDG4) in Sub-Saharan Africa, including Ghana, was a shortage in the number of professional teachers to man pre-tertiary schools (Akyeampong, 2010), the instructional approaches pre-service teachers adopt to teaching their future students (Akyeampong, 2003; Asare \& Nti, 2014), and the supply of professional teachers (Akyeampong, 2010). Additionally, JUSSTEP (Junior Secondary School Teacher Education Report) asserted that the instructional approach adopted by college tutors in instructing pre-service teachers was didactic and teacher-centred (Akyeampong, 2003), which could influence the instructional approaches their pre-service teachers would select. The IOE (2014) suggested that teacher educators should use instructional approaches such as problem-solving, decision-making, critical and reflective thinking in teaching the 2014 curriculum. Teacher-centred instructional approaches, such as didactic are to be used sparingly as compared to learner-centred ones. With the advent of the teacher education curriculum framework the core rationale was to prepare an effective teacher to influence learning in the basic schools (MOE, n.d.). The study, therefore aimed to examine Ghana's attempt to find an effective teacher, in relation to sustainable education, through teacher education reforms. The research questions that guided the study were:

1. What are the problems with Ghana's teacher education reforms not meeting societal expectations of an effective teacher?

2. How would Ghana achieve sustainable education through teacher education reforms?

Curriculum reform is a complex process (Deng, 2013; OECD, 2019; Reis, 2018) because, according to Deng (2013, p. 3), "in curriculum reform the process of curriculum making involves formulating a reform vision and goals, translating the vison and goals into curriculum structures, programmes and courses of study, and implementing reform-induced changes in schools and classrooms". In this process, the elements of curriculum planning and development depend on the country, type of education and training, and institution (CEDEFOP, 2012). Teacher education and curriculum reform should always remember that people are the crucial element of education enterprise (Perez, 2005).

Curriculum reforms are dependent on models that are content-driven, process-driven, objectives-driven, and competence-based curricula. According to Westbrook et al. (2013), most curriculum reforms are to change content-driven curriculum to process-driven or objective-driven curriculum. However, according to Forlin (2010), reforms in teacher education are implemented to internationally transform teacher education to prepare pre-service 
teachers to meet the inclusion. Then, reforms in teacher education should be initiated as a national response to challenges of globalisation (Deng, 2013). The national response should be in line with developments and changes in social, economic, and political context (CEDEFOP, 2012; Reis, 2018). For this reason, there are three levels of curriculum planning and development: 1 . National curriculum concerning curriculum structure, programmes, and subjects developed by the Ministry; 2. Local curriculum concerning special courses developed by local department of education; and 3. School curriculum concerning special courses developed by individual schools. These three levels of curriculum planning and development are faced with global challenges, regional challenges and internal challenges of education systems (Jadhav \& Patankar, 2013).

Additionally, there are three identified levels of curriculum reforms: 1 . Policy which is the discourse of the meeting point of school, culture, and society; 2. Programmatic which is the translation of aims, ideas, and expectations at the policy level to operational framework; and 3. Classroom which is the interpretation of pedagogy of the operational framework by a teacher. These levels show that teachers should be considered as curriculum makers (Deng, 2013). However, studies reviewed by Westbrook et al. (2013) showed that teachers were less likely or not involved in curriculum planning. Stakeholders called for reforms in teacher education curriculum to provide context and culture fitness, but it was not always possible to achieve the extent stakeholders look for (Forlin, 2010). This is because the quality of education is dependent on economic, political, and educational considerations. Amongst them, the political dimension considers the social and political conditions of a country (Deng, 2013). Teacher educators should appreciate the role of politics and economics in curriculum reforms which form the grounds of conflict amongst stakeholders (Perez, 2005).

Any reform in teacher education should orientate pre-service teachers to be practical in acquiring knowledge (Forlin, 2010; Matunhu, 2012). The practical-based training, such as after-school and community outreach programmes will help to integrate pre-service teachers into their communities of practice (Perez, 2005). According Akyeampong (2017), Ghana's 2004 education reform incorporated practicum to teacher education programme to enable pre-service teachers practice in real classroom context. In 2014 the teacher education curriculum offered pre-service teachers one semester as their on-campus practicum and another semester off-campus practicum in their third year of diploma in basic education (Akyeampong, 2017; IOE, 2014). Another key element in curriculum reforms seeking practical approaches was in the area of innovation (Westbrook et al., 2013) relating to transformation of teacher professional classroom practice (Williamson \& Payton, 2009). Examples of innovations in teacher education in Ghana were change from Teacher Certificate 'A' to Diploma in Basic Education (MEYS, 2004) and from Diploma in Basic Education to Bachelor of Education (Basic Education) (MOE, n.d.). Asare and Nti (2014) advocated that any reform in teacher education should incorporate innovative approaches to prepare pre-service teachers as active participants (Forlin, 2010) to influence active learning of their students.

From the review this far, there appears to be numerous issues with teacher education. This study sought to use qualitative methods to examine reforms in teacher education in Ghana from the perspective of a major stakeholder, teacher (herein called 'teacher educator') whose rightful place in curriculum planning and development seems to be downplayed by policymakers.

\section{Research Site, Participants, and Methods}

This study used qualitative approaches (Cohen, Manion, \& Morrison, 2007) in examining Ghana's search of effective teacher, in relation to sustainable education. To be able to achieve this, documents on teacher education reforms were analysed using content analysis through coding of transcribed data, categorising data based on meanings we made, comparing the categories, and drawing conclusions (Cohen et al., 2007). Observations were made of college facilities by the researchers in 10 colleges of education within 5 weeks and 10 teacher educators interviewed within the period. Teacher educators from all the five zones of colleges of education in Ghana were targeted to participate in the study as they had experienced the implementation of various Initial Teacher Education curriculum reforms.

In Ghana, teacher education is an important sector of the economy that attracts a lot of applicants from senior high schools across the length and breadth of the country. To accommodate this large number of prospective applicants, 46 government-assisted colleges of education were zoned into five. The five zones were: 1. Central and Western (15.2\%), 2. Volta (15.2\%), 3. Eastern and Greater (19.6\%), 4. Northern (21.7\%), and 5. Ashanti, Bono, and Ahafo (AshBA) (28.3\%). The 46 colleges of education were mandated to award Diploma in Basic Education to their graduating students as propound by the 2004 education reforms (MEYS, 2004), and the certificates were awarded by the University of Cape Coast. However, during the 2018-2019 academic year, the colleges were mandated to award Bachelor of Education (Basic Education) degrees to their graduating students. The first graduating batch will be offered in the year 2022. The first Bachelor of Education (Basic Education) degrees, at the college level, will once 
again be awarded by the University of Cape Coast for the 2022 year group.

In addition, in the year 2019, the Government of the Republic of Ghana affiliated the 46 colleges of education to five public universities. This became necessary as the government now began searching for effective teachers to facilitate teaching and learning in the Ghanaian basic schools. The proportion of colleges of education in relation to the five affiliate institutions were: 1. University of Education (32.6\%), 2. University of Cape Coast (30.4\%), 3. University of Ghana (13.0\%), 4. University of Development Studies (13.0\%), and 5. Kwame Nkrumah University of Science and Technology (10.9\%).

The 46 colleges of education offer students Technical and Vocational, Early Childhood Education, General Education, French, and Science and Mathematics programmes. The colleges were affiliated to the public universities with respect to their areas of specialisation. For instance, some of the colleges offering Science and Mathematics programme were affiliated to Kwame Nkrumah University of Science and Technology and most of the colleges of education offering Technical and Vocational programme were affiliated to University of Education, Winneba.

Of the five zones, two colleges were simple randomly selected to form part of the study area providing a total of 10 colleges of education that formed the study participants. The simple random approach was intended to give teacher educators of each college and zone equal chances of participation in the study and participants from 10 colleges were deemed sufficient for an in-depth knowledge on finding effective teachers for basic schools through teacher education curriculum reforms. From each of the 10 colleges of education, there were teacher educators with over 10 years teaching experiences and considered to have considerable classroom experience over a decade of teaching at the colleges. Of these experience teacher educators, one was purposively selected for the interviews from the 10 colleges. The purposive sampling approach was important to the study as we needed teacher educators with rich classroom experience and in-depth knowledge in teacher education curriculum reforms. On average, the 10 teacher educators, comprising seven males and three females, had 13 years of teaching experience in the colleges.

The main mode of data collection was semi-structured interviews schedule accompanied with content analysis of documents on teacher education reforms and observations of college facilities. Interviews were important to this study as the study needed to explore the feelings, motivations, and past experiences of teacher educators who participated in this study. As the interview schedule was semi-structured type, all teacher educators responded to similar basic questions such as:

1. How long have you been teaching in the colleges of education?

2. How do you assess teacher education in Ghana?

3. How effective are reforms in education towards teacher preparation?

4. What should be the way forward for sustainable education through teacher education reforms?

The semi-structured interview schedule was important for this study as we were not aware of all issues informing Ghana's teacher education reforms as she searches of effective teachers for teaching in the basic schools. The semi-structured interviews also afforded the participants opportunity to freely express their views on teacher education curriculum reforms. It was, therefore, difficult to craft all questions needed as part of the interview schedule. Consequently, any unique issue that emanated from previous interviews was used in the subsequent interviews with other teacher educators.

Observations were made within 5 weeks at the selected colleges in the form of field notes. The 10 colleges were visited in person by the two researchers independently, five Colleges each, over three days with the selected teacher educator observing the equipment and facilities available for preparing students as pre-service teachers. They also noted the lecture halls, libraries, ICT and science laboratories (where applicable) to ascertain the state of these facilities.

From the observations and interviews, data collected were partially transcribed, as the visual and non-verbal aspects of the interviews with the teacher educators were neglected (Cohen et al., 2007), and grouped based on issues raised by the teacher educators. The issues were deduced from the major areas of the semi-structured interview schedule, and the views of the teacher educators under each issue were constantly compared and meanings made of them. Thereafter, themes were deduced based on our conceptualisation of issues. Six themes evolved as: students' quality and entry requirements, changes in curriculum, role of development partners, neglect of cultural context, support systems, and educator professional development. Sample contents and statements from respondents and observations were placed under each theme. In addition, samples of the content analysis were sent to the teacher educators to agree or reject our perspective of their views. Their critiques and suggestions helped improve how we have analysed 
the data collected. To further ensure the dependability of the data and analysis presented here, the themes and sample content and statements were given to two researchers for critiquing and making suggestions. This helped in improving on the quality of the analysis of data presented.

\section{Results}

\subsection{Problems of Teacher Education}

Reforms in Ghana's teacher education were mostly led by the Institute of Education, University of Cape Coast up until 2004. In all these years, there seem to be issues with teacher education. The three themes that emerged as issues of teacher education in Ghana were:

1. Students' quality and entry requirements; the qualification from senior high school with which applicants were admitted into colleges of education.

2. Changes in curriculum; the numbers of curriculum planned and implemented in colleges of education.

3. Role of development partners; the influence of countries and agencies that support Ghana's education sector through donations, aids, or grants.

\subsubsection{Students' quality and entry requirements}

There had been a number of curriculum and reforms in relation to teacher education in Ghana dated pre-independence to-date. These were aimed at attracting the best for teacher education and to achieve quality basic education. Samples of such reforms came with:

1. 4-year Certificate ' $A$ ' in the 1930 for training middle school leavers for basic education (as primary and middle schools),

2. 2-year Certificate 'B' in the 1937 for training middle school leavers as post-middle for primary schools,

3. 2-year Certificate ' $A$ ' in the 1950 for training secondary school leavers as post-secondary for middle and secondary schools,

4. 2-year specialist and 3-year diploma in the 1962 as a top-up for all Certificate 'A' holders,

5. 3-year Certificate ' $A$ ' in the 1978 for training secondary school leavers for basic education, and

6. 3-year Diploma in basic education in the 2004 for training secondary school leavers.

These reforms and its programmes have come with various requirements, however, for the purposes of this research, the admission requirements for the Diploma in Basic Education introduced in the 2004 and the Bachelor of Education in the 2018 are presented and discussed. Over a decade ago, the mode of entry into the colleges of education was a graduation from second cycle institutions known as senior high schools. However, the requirements varied year after year. For instance, the 2015/2016 requirements for the Diploma in Education applicants were: Credit level (from grade A1 to C6) in five subjects including three core subjects and two elective subjects for WASSCE applicants; and Credit level (from grade A to D) including three core subjects and two elective subjects for SSSCE holders.

The 2016/2017; 2017/2018; 2018/2019 requirements for Diploma in Education applicants were: Pass level (from grade A1 to D7) in six subjects including English Language and Core Mathematics and three elective subjects for WASSCE applicants; and Pass level (from grade A to D) including English Language and Core Mathematics and three elective subjects for SSSCE holders.

The 2019/2020; 2020/2021 requirements for Bachelor degree in Education applicants were: Credit level (from grade A1 to C6) in six subjects including English Language and Core Mathematics and three elective subjects for WASSCE holders; Credit level (from grade A to D) in six subjects including English Language and Core Mathematics and three elective subjects for SSSCE holders; and Credit level in three core subjects including English Language and Core Mathematics and Pass level in three elective subjects for *TVET holders.

* TVET is Technical Vocational Education and Training

The teacher educators interviewed were of the view that notwithstanding the variations in the admission requirements to suit the demands of time, the requirements were the same as the traditional universities. This could not necessarily be true for all years as the traditional universities did not accept five credits in the 2015/2016 academic year but six. The teacher educators shared that the difference was the colleges of education barely attracted the best amongst applicants for a particular year. Oboo, an educator from the AshBA zone explained that, 
As I indicate earlier, in most cases the colleges don't attract the best qualified students and that is our problem... somebody having that wonderful grade will prefer going to the traditional universities.

The colleges of education may not have attracted the best applicants as pre-service teachers for the award of Diploma after completion compared to the traditional universities, where pre-service teachers were awarded Bachelor degrees. The teacher educators believed that this may change now that the colleges of education are offering pre-service teachers Degree programmes. Krakyi, a teacher educator from the Northern zone expressed that,

... of course the same requirements ... two people need to have the same requirements ... one had his/her way into the traditional university to go and pursue a degree and the other person finds his/herself in to the college of education ... invariably the one from the college is seen as lower than the one from the university ... perhaps that is not making the colleges attract quality students from SHS level. So, I think with the introduction of the degree, I will say that disparity which is not encouraging others is now taken care of.

Oboo stated that,

Perhaps it is because when the person is admitted into the university the person will go and pursue a degree programme but the college of education until recently, it is diploma ... so the colleges don't attract the best in terms of weighing the two levels ... diploma level and university level ... they will choose the colleges of education as the last resort.

Notwithstanding the unattractive nature of colleges of education to quality applicants, at times the colleges do attract. That is, there are times applicants with exceptional academic qualities are attracted to the colleges for one reason or another. Even when applicants with good grades are attracted to the colleges they rarely become effective because some teacher educators do not have the capacity to prepare pre-service teachers as compared to the traditional universities. Yakubu, a teacher educator from the Eastern and Greater zone mentioned that;

Some students come with good grades, but when they come to college the problem is compounded. The teachers teaching them are products of an already a weak teacher education system who can't impact ... this will not attract good students like the universities.

Quality students may not be attracted to the colleges of education as some teacher educators indicated, as the Diploma in Basic Education programme is not attractive to these students. The programme should be structured as it is for the traditional universities to attract those quality students. Tetteh, a teacher educator from the Eastern and Greater zone explained that,

A relook at those who have the interest in becoming teachers is important here ... yes, but if the curriculum addresses the needs of those who are interested good students will be attracted, not just because we need teachers anybody at all should come.

Sarpomaa, a teacher educator from the Volta zone stated that,

I'm for this current reforms in education. Colleges of education are going to have their rightful place in preparing pre-service teachers for basic schools. I know next academic year bright students will apply for the college because of the introduction of degree programme.

\subsubsection{Changes in curriculum}

The curriculum used by the Colleges of Education drew a lot of attention from the teacher educators who participated in the study. Many initial teacher education curriculum-related issues were handled by the Institute of Education, University of Cape Coast. The curriculum, according to some of the teacher educators was not structured well to suit the characteristics of basic education in Ghana because the earlier curriculum could not differentiate any different training for a 2-year kindergarten, 3-year lower primary, 3-year upper primary, and 3-year junior high school. Teachers indicated that,

... yes, the curriculum is not structured to train for different levels of the basic schools. The curriculum is a general curriculum to train teachers so that they have general knowledge. So this leads to lack of specialisation in the policy (Afari, teacher educator from Northern zone);

The problem is with the curriculum and it is not structured like that of the traditional universities. The university train B.Ed. students for specific levels of pre-tertiary education but ours is not like that ... it is too general and one can teach everything to any class (Mawuli, teacher educator from Central and Western zone); and

The problem has to do with the curriculum ... it does not solve the problem of prevailing condition of the basic schools, you see... it's a general programme and teacher trainees are not prepared for the different levels of basic 
schools (Oboo, teacher educator from AshBA zone).

The shortfall in the Diploma curriculum in terms of structure was addressed in the year 2014 when the five-semester programme was introduced by Institute of Education (IOE, 2014), leading to the introduction of the Diploma in Basic Education (Early Childhood) for students in some selected colleges of education. Sarpomaa expressed that,

So many have happened with the curriculum for colleges ... though we used to have general programme for all colleges but there were some with French, Technical, Science and Mathematics programmes for JHS level. Let me add that even today some colleges train teachers for early childhood education.

With the advent of Bachelor of Education (Basic Education) programme in the colleges of education, the structure of the basic education was taken care of because various Bachelor degrees will be awarded to pre-service teachers upon completion. Ababio indicated that,

It used to be the case that diploma in basic education programme brought a generalist teacher teaching at all levels of basic education. However, the degree programme comes with Bachelor of Education (Basic Education) with specialisation in Primary School Education, JHS Education, Science and Mathematics, Early Childhood Education, Technical and Vocational Education, and French.

The selected teacher educators were also interested in the approach to planning and development of teacher education curriculum. To some, it was top-down approach with little or no involvement of educators in the colleges. Apam, a teacher educator from Central and Western zone explained that,

any foundation student of curriculum will know that a curriculum will be effective if a change of curriculum will yield the desired results, I won't say 100 per cent, it will yield the desired results if it is approached from bottom up ... the teachers are the implementers in the classroom and should be consulted, then school management, parents, and then it moves on to those in charge of curriculum design, NaCCA.

Effraim, the other teacher educator from the AshBA zone stated that,

As a tutor at the college I can't make any input into the curriculum. You see, the tutors of colleges of education are not involved in drafting the college curriculum so if you have any suggestions you keep to yourself ... there's a challenge with the view to improving the curriculum.

Tetteh explained that,

... who are the implementers of content of curriculum? Is the teachers in the classroom? They should be consulted, then school management, parents, and then to those in charge of curriculum research and development ... but rather they decide at the top and bring it wholesale without adequate training, orientation, or adequate refresher courses to implement the curriculum.

In other instances, the teacher educators explained that teachers were involved in the planning and development of teacher education curriculum. This is because all the stake holders were consulted during the planning and development of the new teacher education curriculum as an example of a bottom-up approach. Ababio commented that,

For the first time after the curriculum was developed you can see that the body that matter most, directed that there should be certain number of the compositions from all implementing stakeholders. Which the college tutor is part.

Sarpomaa further stated that college tutors were involved in the process of planning and development of the new curriculum for colleges of education;

... they asked the college teacher association to submit 5 additional people, which the association did and it spans across all subjects. So, this is a curriculum that has had the direct impute by the teacher in the classroom. There was nothing to begin with, but the teachers themselves had to bring the ideas to the curriculum what we have today.

The change in the colleges of education curriculum from Diploma in Basic Education to Bachelor of Education (Basic Education) was considered as just a change in name sake but not the content and the quality of training. Effraim stated that,

The curriculum the curriculum is just a name change but not in the training. I for see the courses will be the same and only be spread for four years. ... I said earlier the colleges on the field are hardly involved in the designing the new degree curriculum.

In other instances, the teacher educators shared that the change in curriculum for colleges of education was not just a change in name but the problem will be having the requisite manpower to implement the Bachelor of Education 
curriculum. Krakyi explained that,

And again, when these things are carried out, when these things are brought, the need for requisite manpower even if you want to change this curriculum or to move from a different level to award a different degree, the needed manpower to implement it has not been prepared for.

Others however, were of the view that the change in curriculum was not just a name change but rather the demands of the training will be reflected. Ababio mentioned that,

Not just changing the name to reflect ... whether it is a degree but it is the curriculum that necessitated the award of the degree. And it should be in line with the amount of work. So if the amount of work you are doing corresponds to the work someone is doing to get a degree in some other institution, why then go through a four year programme to prepare as a teacher, and at the end given a certificate or diploma.

Sarpomaa explained that,

... So, the name, to some extent, imply that they are changing the name to mean just that as they did for the cert A to diploma ... they just changed the name without any difference in what the Certificate A people and the Diploma were doing, there's no much difference. ... for the Diploma to Degree, there's a huge difference in terms of the teaching, preparation, everything is entirely different. So, the change came about as result of the amount of work that has been developed for the curriculum.

The amount of work in the content will ensure that the pre-service teachers have the right content and pedagogical knowledge to effect the change government and society were looking for. Hence, the introduction of Bachelor of Education programme at the colleges of education was appropriate. Yakubu indicated that,

... I want to see a teacher who is trained well with respect to the content as well as the pedagogical fields. So where you, a teacher is well trained with the content without the pedagogy is somehow too skewed ... PCK being done concurrently; teaching the pedagogy, teaching the content and having the practicum is what the new degree curriculum offers students.

\subsubsection{Role of development partners}

Another problem associated with teacher education in the colleges of education was the influence of development partners. Some development partners supports the education sector of the country's economy with donations, aids, or grants. This led to the belief that educational reforms were basically influenced by the partners as they were interested in seeing their assistance put to good use. Tetteh explained that,

On the various reforms I think that the intent was to meet international standards if not why change from diploma to degree. ... ideally my expectation is that if a student completes college of education out of this reforms, the person should be able to teach at the basic school level in such a way that mass failure can be reduced ...

The development partners came with conditions. Some teacher educators explained that the problem with teacher education in Ghana and its reform was that the curriculum has failed to meet the needs of Ghanaian society due to the expectations of development partners. Apam expressed that,

Exactly! The shortfall comes from the curriculum which is influenced by donors, not even at the needs of Ghanaian society and that is why students graduating from the colleges over the years look for better opportunities elsewhere instead of staying in the classroom and teaching Ghanaian children.

Tetteh stated that,

So, if we were training to meet the local content, to meet the needs of society (Ghanaian society), donors will not have much influence. ... I don't think those who have been trained will leave their profession for other profession. Our education is influenced basically by donors and this one too I'm sure is the same old story.

The curriculum failed to meet the needs of the Ghanaian society as development partners were seen to influence reforms in the education sector because Ghana could not single handedly fund education, and teacher education was not left out. Effraim explained that,

... funding Ghana education has always been in partnership with international and multi-national organizations who give conditions A or B to be met before giving the grant or loan. Currently, there's ongoing reforms largely influence by a multi-national agency interested in transforming teacher education and learning and their views are respected by all colleges, though we have questions.

Ghana should own its reforms and curriculum to make significant impact in the area of teacher education. Yakubu 
indicated that,

Is a foreign agency interested in transforming teacher education and learning leading the curriculum team for the degree programme ... I think we Ghanaians should own the curriculum but not the international organization that seems to be giving directives on how our curriculum should be planned and run ... Their teacher education may be good to them but not us. Different country different challenge oh!

Some of the teacher educators were of the view that though the organisation for transformation of teacher education was not Ghanaian-owned, their support to the reforms in the teacher education sector was important and timely. There was due consultation but not imposition of ideas by a multi-donor organisation. Sarpomaa explained that,

That is a total falsehood ... If you look at how the framework was developed, all peoples who matter were consulted, it was quiet amazing ... there were former principals of two or so colleges of education, executive secretary of the national inspectorate board, consultant teacher education division, pre-tertiary teacher education, and professional development and management ... so it is never the case that it's a foreign curriculum.

Afari stated that,

... though these transformations were brought up based on a help of a foreign sponsored programme and the curriculum was written by Government and People of the Republic of Ghana. So, it wasn't like it was given to us but it was written by us and we took it out to seek for sponsorship to implement it.

Sarpomaa added that,

For the first time in this country we have national framework informing any future reforms in the teacher education. All these thanks to the agency for transforming teacher education and learning in Ghana.

Ghana was interested in reforming its teacher education sector but could not act in isolation because of globalisation and global dynamics. Everything that happened in one country had rippling effect on another. Ababio explained that,

Now when we say our system, education has a universal complement of it. A certain level of universality when we talk about education ... if you are a curriculum planner ... look at the best practices and adopt to suit your system.

Mawuli stated that,

So yes, we might have a particular system, we might be doing in a certain way, but if you look at the new direction that education is moving globally, you adopt the best practices and ... yes, you might say that is the donor partners and all that might try to push out in a certain direction but their support, both technically and financially are important.

\subsection{Suggestion for Achieving Sustainable Education thorough Teacher Education Reforms}

The selected teacher educators shared their views on how to achieve sustainable education through reforms in education. To solve the problem associated with the current teacher education programme in the colleges of education leading to sustainable education, in preparation of effective teacher, there was the need to give some considerations. Three other themes emerged from the interaction with the educators and observations that included the:

1. Cultural context, which is the Ghanaian dynamics of education suitable to the sociocultural and economic needs of the people.

2. Support systems, which is the presence or otherwise of contemporary materials and services needed for effective training of pre-service teachers, to use modern instructional strategies.

3. Educator professional development, which is the support services to be provided for teacher educators to bring them up to speed with modern trends of teaching and learning in higher education.

\subsubsection{Cultural context}

The idea of reforms in teacher education was a welcomed initiative. However, there was the need to appreciate that colleges of education were mandated to prepare pre-service teachers for Ghanaian basic schools, and any reforms in education sector should not lose sight of this. Ababio explained that,

... per the mandate given to the colleges of education in Ghana, currently, we are basically training teachers, the manpower requirements for basic schools (primary schools and junior high school) in Ghana. ... and our products are posted to teach in the basic school per our mandate.

Krakyi also stated that, 
... we should in our desire to change our system in terms of maybe awarding higher degree. If we think that other nations are going that way, we should fashion ours to look at our culture, our needs in terms of teacher education, and what we want our citizens to become and not to pick other people's modules ... forgetting about our culture, our geographical location and our current educational system.

The basic schools were very critical to achieving anything meaningful for the country. For this reason, any sustainable teacher education, in our context, should first target teacher training that practically meet the needs of the people but not theory as in the case of many previous reforms. Oboo suggested that,

To a large extent .... That's what I meant by too bookish because it doesn't take into consideration our needs. Leaving out the practical aspect of the training where the trainees will meet the situational problems of what they are learning. This is what I will recommend.

Effraim stated that,

I want to see a teacher education, where our products can solve the problems of the country ... because today's challenges will not be the same as tomorrow and trainees should be given the requisite skills to solve societal problems ... so that what we learn in the classroom should help solve societal problems ... so that our basic schools, relative to our senior high school can be comparable to any other products in the world.

For the current dispensation, the basic school consisted of four levels of learning and each level required specific content and pedagogy for instruction. Hence, specific training was required to prepare teachers for these levels. Apam mentioned that, for sustainable teacher education,

the basic schools have different levels, especially now that our country the Kindergarten is part of the basic school structure: Kindergarten 2 years, then 6 years of Primary education, then 3 years of Junior High school, different training is needed for our children and when you train somebody you should be sure the fellow can teach in a specific level.

The basic schools were spread across the length and breathe of Ghana and most of these communities had been deprived of social infrastructure. Consequently, not all technology-based instruction could suit learners from these deprived communities. For sustainable, Mawuli suggested that,

The Ghanaian culture is important when it comes to reforming teacher education. The reforms should spell out how those who will be for kindergarten are to be trained, those who are going to be trained for lower primary, that of upper primary and then the Junior high school are to be trained; and even the various subjects.

Afari added that,

You mean sustainable education? ... you are here now and I will take to schools in some communities to appreciate why colleges need to be resource to train specific teachers for some schools in some communities. This is Ghana and we need to appreciate the cultural and geographical dynamics.

Oboo stated that,

For sustainable education, some specialised teachers are needed for the schools in rural areas as compared to those in the towns and cities. The rural communities don't have good classrooms and even to talk of having ICT materials for modern modes of teaching. ... even our college has challenges with needed ICT materials.

Ghana has an insufficient number of professional teachers to manage the basic schools. Some teachers were encouraged to provide assistance in some subject areas though they had no expertise of. This was the kind of context within which most Ghanaian teachers practice their trade in the basic schools. Tetteh suggested that for sustainable education,

There should be a policy on training of some subject-teachers to meet what we experience in this country. ... some colleges offer students French, and others Technical or Science. But this policy trains students in these special areas, for example, somebody doing French is not supposed to offer English but the fellow finds him/herself in a school where he/she has to teach all the subjects.

\subsubsection{Support systems}

For sustainable teacher education, there was the need to equip the colleges of education with materials and services that would strategically positioned them to prepare pre-service teachers to use contemporary technologies to instruct lessons in basic schools. Upgrading colleges of education from Diploma awarding institutions to Bachelor levels should go with systems upgrade. Apam indicated that. 
... And let me put it this way too, we are only making changes from diploma to degree without making any efforts to change our system, e.g., classroom structure, qualification, admission, etc. ... so when donor funds are exhausted and the country is back to square one then we are found wanting.

Ababio stated that,

Now, exactly, for sustainable education, a change is needed in the area of college systems. Because our local resources and weak services will not be able to support the change ... things will collapse into the old system of doing things after the change.

The colleges of education needed to improve on the physical structures, such as lecture halls, demonstration rooms, ICT and science laboratories, and fields for sports activities. Oboo mentioned that,

Any change is important for sustainable education but it should go with improved infrastructure. Many colleges do not have what it takes for tertiary training of students, e.g., small classrooms which I will not call lecture halls, small library, to me are just reading rooms, and old facility as science labs ... that is support systems to train students at this level are not there.

Afari stated that,

... you see this science laboratory is furnished and handed over to the college but we can't use it ... the taps are not flowing with water. College management cannot work on it as they say is against some laws and auditors will query it.

There were insufficient ICT facilities in the colleges of education for teaching and to prepare pre-service teachers on how to use them. However, sustainable education needs ICT facilities to achieve its aims. Our observations suggested that not even more than two colleges had interactive boards in their lecture halls. Sarpomaa indicated that,

It is difficult to achieve sustainable education without the use of technology. There are say one or two projectors here and I think most colleges are facing same challenge. How then do we lecture students using modern strategies to help them to learn from us?

Afari stated that,

Is not a matter of not having sufficient ICT materials? Though we have few projectors in the ICT lab and no interactive boards. This prevents teaching through modern approaches. For where we are going now (that is degree level) and sustainable education, colleges will need to be equipped ...

The selected teacher educators expressed that provision of guidance and counseling services in colleges were crucial to sustainable education i.e. pre-service teachers needed to be guided to make the right choices. Though our observations showed that the selected colleges of education had a unit called Counselling Unit but was not that functional. Krakyi explained that,

One of the support systems is the guidance and counseling unit to guide these young ones in their formative years to know their interest, their potential, and to give them the needed guidance to choose programmes in their interest areas and the areas where their potentials can be unearthed...

Yakubu stated that,

Our students are mostly interested in the monthly allowances and ready employment and changing from diploma to degree calls for some sort of counseling to prepare students for challenging academic work. For sustainable education, there is the need to have vibrant guidance and counseling unit in the colleges to help students in this direction.

\subsubsection{Educator professional development}

The colleges of education were classified as tertiary institution. This status was due to their accreditation to award diploma in basic education to graduating pre-service teachers. Teacher educators in the colleges were therefore required to have a professional qualification of research-based master's degree. This qualification, some educators had and others, were yet to have. Yakubu suggested that,

For sustainable education, I think we, college tutors will need to upgrade. The upgrading will strengthen us in the pedagogy and even enhance the teaching of the content.

Effraim stated that,

for sustainable education, is a long way to go ... is true that some of us have post-graduate qualifications but others will need to go for further studies ... the tertiary level professionalism come with its own challenges and that those 
who don't have the basic qualification, will need it.

Some teacher educators were asked to stay of supervising pre-service teachers' project work. The project work was an opportunity for pre-service teachers to embark on research in the field of social sciences. This became necessary as those educators did not have qualification in research-based Master's degree, the minimum requirement and hence, cannot supervised project work. Sarpomaa indicated that,

For sustainable teacher education in Ghana, professional development is key. ... for almost 3 years ago, our members with no research-based master's degree were excluded from supervising students' project work and it was an issue.

Apam stated that,

... though we are used to having professional development sessions as directed by transforming teacher education and learning in Ghana, weekly programmes in the colleges but this did not safe most of us, our job. ... upgrading to the master's level is the solution and that there should be opportunities for colleagues.

College-based Professional Development Sessions (PDS) were encouraging in terms of sharpening the pedagogical knowledge of teacher educators. Teacher educators were happy with their weekly PDS. However, the PDS came with no job security. The only job security was having the basic qualification of research-based Master's degree. For sustainable education, there was the need for mentoring institutions to organise upgrading (short) courses leading to the award of research-based Master's degree for teacher educators. Ababio suggested that,

The time has come for our mentors to offer us a helping hand in upgrading to the required Master's degree. To me some short courses tailored to meet the needs of colleges of education will help as a professional development.

Mawuli stated that,

The weekly PD sessions are interesting and achieving some targets but is all about qualification. I encourage anyone interested in working in the college to go for research-based Master's degree. ... the mentoring institutions should help and should not just pressure us to have the qualifications.

Publications are one of the important dimensions to working in the tertiary education sector. However, publications in both international and local journals are a deficit in the trade of teacher educators in the colleges of education. The teacher educators felt that some of their PDS can be taken by the mentoring institutions to enhance the educators' research and academic writing skills. Afari suggested that,

I think we at the college level need support in doing research. ... I wonder how many of my colleagues have made an attempt at doing this. If the experienced researchers in the universities can come in during our PDS, it will be enormous help. I am calling for this as a way of sustaining teacher education.

Ababio stated that,

For the purposes of our stay in the colleges, we are asked to publish in journals (both home and abroad) and this is not easy for us. I think we need some support here. Our former university of affiliation has once organised a workshop on action research and more will be needed ...

\section{Discussion}

The 2004 education reform in Ghana introduced the Diploma in Basic Education in the colleges of education (Akyeampong, 2017; MEYS, 2004) which has helped to have professionals of some sort of high caliber teaching in basic schools. Thereafter the 2014 reform attempts have been made over the years to attract students to colleges of education, but these attempts seem not to attract quality students to be prepared as pre-service teachers for basic schools. Even the UTDBE programme brought to the colleges many students who ordinarily would not have gained admission making the system of admission to colleges unstructured (Acheampong, 2003). The finding that colleges of education hardly attract quality students graduating from high schools is something that calls for concern of all stakeholders in teacher education because the sustainable development goals (SDG4) is not only interested in access to quality education but the availability of professional teachers, a challenge in Sub-Saharan Africa (United Nations, 2017). MOE (n.d.) has, as one of its policies raising the profile of teaching to attract the best to colleges of education. One of the areas with which this can be achieved is through raising the standard of entry requirements. For quality education, effective teachers are a necessity and policymakers should provide incentives (United Nations, 2019) to attract the best students to the colleges of education.

The increasing number of pre-service teachers in colleges of education are not academically apt but are attracted by monthly allowances given to them as motivation (Akyeampong, 2003). As much as we need numbers to help man 
basic schools, there is the need to attract the best (quality) of applicants to be prepared as pre-service teachers. The introduction of Bachelor of Education (Basic Education) programmes in colleges of education in 2018 could end the unattractiveness of colleges to quality students because the 2022 graduating students from colleges of education will then have equal and quality certificate as those graduating from traditional universities. Policymakers are, therefore encouraged to reach out to students from senior high schools to sell what the colleges offer to attract them.

Identification of the Diploma in Basic Education curriculum shortfalls over the years not addressing the special nature of basic school system is a positive move as MOE (n.d.) seeks to addressing that shortfall by deepening pre-service teachers' knowledge with the introduction of specialisations as Kindergarten to Primary 3 (early childhood education), Primary 4 to 6, JHS 1 to 3, and SHS 1 to 3 into teacher education curriculum in Ghana. This is what the teacher education curriculum framework seems to address since its introduction in the 2018/2019 academic year in the colleges of education. The National Council of Tertiary Education (NCTE) and National Council for Curriculum and Assessment (NaCCA) should, therefore educate the colleges of education community the new curriculum structure for preparation of pre-service teachers for basic education. The finding that any reform in teacher education should be practical-based is in line with one of the aims of the new Ghanaian teacher education reforms (MOE, n.d.); something noted earlier that it can help in development of Africa (Matunhu, 2012). Currently, the national teacher education curriculum reforms seeks to use practical-based teaching to help pre-service teachers learn. This is achieved through supported and assessed teaching in basic schools during the preparation of teachers.

Though there is curriculum framework for teacher education to inform review of the new Bachelor of Education curriculum for colleges of education (MOE, n.d.) but a comparison of the assertions of teacher educators to the list of stakeholders, who are the members of National Technical Committee on Teacher Education Curriculum Review shows the reforms was top-down approach. This is because only recognisable leaders of their departments and agencies are involved in the planning and development of the curriculum as experts. The teacher educators who have been implementing all reforms and innovations in teacher education in the colleges of education are significantly absent among stakeholders, even the president of colleges of education teachers association of Ghana (Cetag) or his/her representative is absent (MOE, n.d.). Teacher educators and pre-service teachers are only involved when the curriculum framework was ready and needed the endorsement of all at a National Forum (MOE, n.d.). There is the need to involve teacher educators in teacher education curriculum reforms as active stakeholders to be able to translate and transform the new curriculum from experiences into achieving its goals (Deng, 2013). Going forward, NaCCA is encouraged to start any reform with teacher educators and pre-service teachers to incorporate their experiences and expectations in teacher education curriculum.

Ghana is still in the top-down planning and development of curriculum. An approach most development partners may not be interested today, in their reforms. Some development partners practice the tripartite system of curriculum administration where districts and schools are actively involved in curriculum planning, development, and implementation (Deng, 2013). However, in Ghana little is seen of schools and colleges, who only implement but experts are involved in the planning and development of curriculum. The teacher education curriculum framework would have the needed impact when these little things are well-considered. This is because achieving the desired learning outcomes will depend the how far teacher educators believe that the teacher education curriculum frameworks mirrors best practices of teaching and learning (OECD, 2019) in colleges of education.

There is a teacher education curriculum framework that started in 2015 (Akyeampong, 2017), for informing revisions and reforms of teacher education. The 2015 reform in teacher education is initiated and steered by Transforming Teacher Education and Learning (T-TEL), an agency funded by the UK government. Hence, the 2015 teacher education reform termed as T-TEL reform (Akyeampong, 2017). This goes to support the assertion that development partners influence education reforms to the neglect of Ghanaian context. However, Ghanaian teacher education cannot be structured as that of UK or any other country as there are cultural and geographical dynamics. The framework at a glance is made of four pillars of teacher education including subject and curriculum knowledge, literacy studies, pedagogic knowledge, and supported teaching in school (MOE, n.d.). The framework defines the weightings of the Bachelor of Education curriculum that should go into the specialisations. This is the first of its kind in all education reforms in Ghana. The framework is crucial to reforms in teacher education curriculum (Deng, 2013) and to preparation of pre-service teachers in colleges of education. It is crucial because there is no weighting for previous curriculum for preparation of diploma in basic education teachers. The teacher education curriculum framework and its advent, Bachelor of Education programmes in colleges of education could be the response to the clear dissatisfaction with Initial Teacher Training in Ghana since the early 1990s (Akyeampong, 2003) and the response to the needs of society (Asare \& Nti, 2014) that seems not the case according to teacher educators, who should take control of their own enterprise (Perez, 2005). 
If Ghana's development partners, such as World Bank have been involved in all post-independence education reforms (Akyeampong, 2010), then why are we not there yet in Initial Teacher Education? The cultural context is crucial and should be handled right in relation to revisions or reforms of the teacher education curriculum through best practices from elsewhere applicable to the Ghanaian context (Akyeampong, n.d.). This is because teacher educators feel the cultural context is ignored by Ghanaian curriculum planners. The planners of teacher education curriculum (MOE, n.d.) recommend that colleges of education have high quality demonstration or partner schools for pre-service teacher preparation. This is a commodity that will be difficult to have in most parts of Ghana except regional and district capitals. It is well-documented (United Nations, 2017; 2019) that Sub-Saharan African countries do not have adequate supply to electricity, access to drinking water, toilet facilities, computers and internet for modern pedagogy. This then calls for context specifics in preparing effective teachers to create a conducive learning environment for learners in basic schools (Adu-Gyamfi, 2020) in those communities. A call that is adhered to by most of Ghana's development partners (Deng, 2013). If the leadership of this world asserts that there are disparities in education opportunities, then the same mode of education cannot be modelled for countries across the globe (United Nations, 2019); Ghana must seek solutions to problems of teacher education from Ghanaian perspective (Akyeampong, 2010). Hence, policymakers in Ghana (and other Sub-Saharan African countries) should therefore factor cultural, geographical, and economic contexts in any teacher education curriculum framework to have the needed manpower and impact.

The influence of development partners on teacher education reforms in particular should end at some point in time because the development partners of Ghana's economy seem to support only education reforms that serve their interest making Ghana not to have the best education for meeting the cultural demands and the needs of the society. The teacher education programmes and the corresponding curriculum are foreign to Ghana, and can only provide teacher education. Ghanaian cannot be trained the same way as the Americans, Asians, Europeans and hence, pre-service teachers are trained with student-centred approaches as if they will been training foreign children. Ghanaians believe in the elderly and see them as always right and hence, teachers should be trained to use approaches where the teacher is influencing in the teaching and learning process to support the learner to make meaning of new information.

Support systems such as facilities and counseling units are crucial to any tertiary institution. Teacher educators should be assisted and supported to carry out research and make publications. This will enhance their knowledge, skills, and attitudes to be effective educators as they will get the opportunity to learn contemporary knowledge in their field and to impact same to their students. The mentoring institutions training educators in the colleges of education need to conduct research and make publications with them so as to improve their practice and to contribute to knowledge on teacher education. The leadership of the colleges of education should generate and use internal generated funds to equip their institutions to modern state of art. Continuing professional development is recommended by the planners of the teacher education curriculum framework (MOE, n.d.) as there is no clear-cut approach to it. Hence, the call by teacher educators to have help from mentoring institutions to upgrade to research-based Master's degree and to have their capacity built in research and publication is appropriate. The guidance and counseling units in the colleges of education should be functional and not mere rhetoric to the satisfaction of policymakers. Colleges of education should offer pre-service teachers the needed support to make inform decision of their chosen-career to have impact on basic education in Ghana.

\section{Conclusions}

There have been a number of reforms in Ghanaian education including teacher education, however, these reforms come with associate problems that have not been handled best in the perspective of teacher educators. The problems associated with teacher education in Ghana were quality of students and their entry requirements, changes in curriculum, and development partners and their roles in education. These problems affect the preparation of pre-service teachers in diverse ways, such as quality students not attracted to pursue teacher education in Initial Teacher Training Colleges (colleges of education) but with the introduction of Bachelor of Education in colleges of education things could change for best. Reforms and revisions in teacher education curriculum framework for the Bachelor of Education programme should be minimal and unaffected by changes in political power, but achieved through bottom-up approach where teacher educators and pre-service teachers' views and experiences are respected and factored.

For sustainable education achieving quality, inclusive, and equitable education in basic schools for all persons in Ghana, the cultural context, support systems, and educator professional development should be of interest to policymakers. Though the assistances from development partners cannot be over-emphasized but social, economic, 
and geographical context of Ghana are crucial to teacher education curriculum. This will help Ghana have solutions to its own problems in basic education, and Ghana will have sufficient number of professional teachers motivated enough to ply their trade in basic schools. Upgrading in knowledge and skills of teacher educators is important for teacher education. It is, therefore, recommended that teacher educators should be supported by the mentoring institutions to be grounded in scientific research and publications to share knowledge with colleagues globally.

\section{References}

Adu-Gyamfi, K. (2020). Pre-service teachers' conception of an effective science teacher: The case of initial teacher training. Journal of Turkish Science Education, 17(1), 40-61. http://doi: 10.36681/tused.2020.12

Adu-Gyamfi, S., Donkoh, W. J., \& Adinkrah, A. A. (2016). Educational reforms in Ghana: Past and present. Journal of Education and Human Development, 5(3), 158-172. https://doi.org/10.15640/jehd.v5n3a17

Akyeampong, K. (n.d.). Educational expansion and access in Ghana: A review of 50 years of challenge and progress. Falmer, Brighton: Centre for International Education, University of Sussex.

Akyeampong, K. (2003). Teacher training in Ghana - Does it count? Multi-site Teacher Education Research Project (MUSTER). Country Report One. Sussex: Keith M Lewin and Janet S. Stuart.

Akyeampong, K. (2004). Whole school development in Ghana. A Background paper prepared for the Education for All Global Monitoring Report 2005. The Quality Imperative, UNESCO.

Akyeampong, K. (2010). Educational expansion in Ghana: A review of 50 years of challenges and progress. Falmer, Brighton: CREATE.

Akyeampong, K. (2017). Teacher educators' practice and vision of good teaching in teacher education reform context in Ghana. Educational Researcher, 46(4), 194-203. https://doi.org/10.3102/0013189X17711907

Asare, K. B., \& Nti, S. K. (2014). Teacher education in Ghana: A contemporary synopsis and matters arising. Sage Open, 1-8. http://doi: 10.1177/2158244014529781

CEDEFOP. (2012). Curriculum reform in Europe. The impact of learning outcomes. Luxembourg: Author.

Cohen, L., Manion, L., \& Morrison, K. (2007). Research methods in education (6 ${ }^{\text {th }}$ ed.). London: Routledge. https://doi.org/10.4324/9780203029053

Deng, Z. (2013). Curriculum making in the new curriculum reforms: Structure, process and meaning. Retrieved 2020/04/16, from https://www.researchgate.net/publication/ 285986620_Curriculum_ making_in_the_new_curriculum_reform_Structure_process_and_meaning.

Forlin, C. (2010). Teacher education reform for enhancing teachers' perception of inclusion. International Journal of Inclusive Education, 14(7), 649-653. http://doi.org/10.1080/13603111003778353

Institute of Education. (2014). Three-year diploma in basic education: Five-semester programme (revised syllabus). Cape Coast: Author.

International Council on Education for Teaching. [ICET]. (2012). $56^{\text {th }}$ year book on teacher education. A Collection of Papers and Reports from the 56 ${ }^{\text {th }}$ World Assembly held on 10-12 July, University Of Cape Coast, Cape Coast.

Jadhav, M. S., \& Patankar, P. S. (2013). Role of teachers in curriculum development for teacher education. For National conference on Challenges in Teacher Education, Physical Education and Sports, Mahavir Mahavidyalaya, Kolhapur.

Matunhu (2012). Teacher education and development in Africa: A theoretical analysis. A paper presented at the $56^{\text {th }}$ World Assembly held on 10-12 July, (298-303), University of Cape Coast, Cape Coast.

Ministry of Education. [MOE]. (1993). Report of the education commission on teacher education in Ghana. Accra: Author.

Ministry of Education. [MOE]. (n.d.). The essential elements of initial teacher education. Retrieved, 09 April, 2020, https://www.uew.edu.gh/sites/default/files/Announcement $\% 20$

Teacher\%20Education\%20Curriculum\%20Framework\%20.pdf

Files/National $\% 20$

Ministry of Education, Youth and Sports. [MEYS]. (2004). White paper on the report of the education reform review committee. Accra: Author.

OECD. (2019). Future of education and skills 2030: Curriculum analysis. A paper presented at $9^{\text {th }}$ Informal Working Group (IWG) Meeting, Vancouver, B.C., Canada. 
Perez, D. M. C. (2005). Curriculum reform and teacher education: The loss of innocence. Retrieved 17 April, 2020, from https://files.eric.ed.gov/fulltext/EJ795721.pdf

Reis, S. (2018). Curriculum reform: Why? What? How? and How will we know it works? Israel Journal of Health Policy Research, 7(13), 1-4. https://doi.org/10.1186/s13584-018-0221-4

United Nations. (2017). The sustainable development goals report. New York: Author.

United Nations. (2019). The sustainable development goals report. New York: Author. https://doi.org/10.18356/55eb9109-en

Westbrook, J., Durrani, N., Brown, R., Orr, D., Pryor, J., Boddy, J., \& Salvi, F. (2013). Pedagogy, curriculum, teaching practices and teacher education in developing countries. Final Report. Education Rigorous Literature Review. Department for International Development, University of Sussex, Falmer, Brigton.

Williamson, B., \& Payton, S. (2009). Curriculum and teaching and innovation. Transforming classroom practice and personalization. Penryn Campus: Futurelab Innovation in Education. https://doi.org/10.12968/sece.2009.2.1444 